\title{
The Effect Of Internal Capital Market Of Korean Large Business Groups On Investment Efficiency
}

Minwoo Lee, Yeungnam University, South Korea

Yuwon Choi, Yeungnam University, South Korea

Sanghyuk Moon, Yeungnam University, South Korea

\begin{abstract}
This study examines whether the effect of funding through internal capital markets on investment efficiency is differentiated by the incentives of controlling shareholders as measured by the divergence between cash flow rights and voting rights of controlling shareholders (hereafter, wedge).

To empirically analyze hypotheses of this study, 1,189 firm-year observations were collected from Korean firms listed on the Korea Composite Stock Price Index (KOSPI) belonging to a large business group designated by the Korea Fair Trade Commission over the period from 2005 to 2012. The results of the analysis are as follows.

First, we find that the magnitude of internal funding, as measured by total payables to the related parties, is positively (+) associated with investment inefficiency. Second, the interaction variables of total payables to the related parties and the wedge have a significant positive (+) effect on investment inefficiency. In other words, the deterioration of investment efficiency due to the increase in total payables to the related parties was mainly caused by firms with a big wedge. This result suggests that the effect of internal capital markets on investment efficiency of large business groups may be differentiated by the wedge that is proxy of the controlling shareholder's incentive.
\end{abstract}

This study provides additional evidence on previous studies on the investment efficiency of large business groups by considering both the internal capital market and incentives for funding using the internal capital market, which are important factors affecting the investment of large corporate groups. Also, the results of this study are expected to provide implications for the regulatory policy of large business groups which have recently become an issue in Korea.

Keywords: Internal Capital Market; Investment Efficiency; Large Business Group; Wedge

\section{INTRODUCTION}

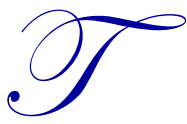

raditionally, large business groups in Korea have been criticized for concentration of economic power, collusive link between politics and business, and maximizing wealth of controlling shareholders (Yim, Lee \& Hwang, 2014). On the other hand, there is a growing interest in the large business groups in the form of ownership management, arguing that aggressive investment by investment banks, one of the causes of the global financial crisis in 2008, is caused by the problem of agents of professional managers. It has also been argued that the development of the Korean economy is due to the long-term and bold investment by large business groups (Lee, Kim \& Lee, 2010; Yim et al. 2014). As result of, the impact of large business groups on the Korean economy can be viewed as significant. Therefore, the study on the investment decision making of the large business groups is very important.

Important characteristic of the large business groups is the existence of internal capital market (Park \& Jung, 2011). Large business groups can be financed within the business group if external funding is difficult or unavailable, or funding costs are high because of the existence of internal capital markets (Shin \& Park, 1999). In addition, if a longterm profitable business is temporarily insolvent, it can continue its business activities by providing funds through the 
internal capital market. In other words, risk diversification can be achieved not only among firms but also over time through internal capital markets (Bae, Lim \& Wei, 2006).

There are two theoretical perspectives concerning the inducement of large business group' funding through the use of internal capital market (Yoon, 2004). First, in the presence of information asymmetry, the internal capital market can be a positive incentive to increase the efficiency of the group as a whole and to increase the profit of each affiliate. In other words, the use of internal funds transactions can avoid information asymmetry existing in the external financial market, thereby increasing the efficiency of fund allocation funds to the entire business group (Alchian, 1969). It can provide low-cost funding opportunities for affiliates that need funding (Khanna \& Palepu, 2000). In this case, if the controlling shareholder of the large business group possesses information superiority compared with outside investors, it can allocate funds to affiliates with favorable investment opportunities and allocate funds efficiently from the groups' perspective (Stein, 1997). From the viewpoint of agent theory, there is the possibility that the internal capital market may contain structural inefficiency. Through the internal capital market, there can be 'socialist subsidies' in which business opportunities with low investment opportunities and low productivity are funded by business units with excellent investment opportunities (Scharfstein \& Stein, 2000; Rajan, Servaws \& Zingales, 2000). In emerging markets where the ownership structure is complex due to the pyramid structure or cross-shareholding, there is also the possibility that the internal capital market will deepen the agent problem between controlling shareholders and minority shareholders (Claessens, Djankov, Fan \& Lang, 2002). In other words, the resources of the business group can be transferred to businesses and affiliates that maximize the private utility of the controlling shareholder. This implies that the internal fund transaction by large business groups may be conducted to maximize utilities of controlling shareholders at the expense of minority shareholders (Yoon, 2004).

As previously discussed, there are conflicting views on the internal fund transactions of the large business group. Therefore, it is expected that the efficiency of internal capital markets, which is one of the important characteristics of large business groups, will differ depending on ex ante incentives of controlling shareholders. This study examines the role of internal capital markets of large business groups in terms of investment efficiency from the perspective of the incentives of controlling shareholders. Specifically, we analyzed whether the effect of size of funding through large internal capital markets on investment efficiency is differentiated by the incentives of controlling shareholders, as measured by the divergence between cash flow rights and voting rights of controlling shareholders (hereafter, wedge).

Previous studies have reviewed the efficiency of internal capital markets in relation to investment efficiency, but have presented mixed results. In addition, most prior studies do not directly consider the role of the internal capital market, which may affect the investment efficiency of a large business group. Even if the existence of the internal capital market is considered, it seems that the controlling shareholders do not properly distinguish ex ante incentive to use the internal capital market. As noted in Yoon (2004), it is vital to understand ex ante motivation in judging the efficiency of internal fund transactions. Therefore, it is necessary to consider both the existence of the internal capital market, which is expected to have a significant influence on the investment of the large business group, and ex ante incentives of controlling shareholders to use internal capital markets. In this study, we investigated the effects of the internal capital market of the large business group on investment efficiency through total payables to the related parties. We also analyze whether these effects are differentiated according to ex ante incentives of controlling shareholder represented by the wedge. ${ }^{1}$

To empirically analyze our hypotheses, we used 1,189 firm-year observations collected from Korean firms listed on the Korea Composite Stock Price Index (KOSPI) belonging to a large business group designated by the Korea Fair

\footnotetext{
${ }^{1}$ On December 21, 2015, the Korean economic magazine 'Invest Chosun' reported the following article on the impact of large business group funding through internal capital markets on investment.

'Hanwha Group to develop defense products, change Hanwha Group's presence: Hanwha Group has begun to put more emphasis on the defense industry. The company is expanding its efforts to mobilize cash through the reorganization of related affiliates and the sale of assets. It is not uncommon for high-quality affiliates to play a major role in funding this process. Hanwha Chemical, whose earnings have improved dramatically, is also emerging as one of those ... There is a similar precedent. Hanwha Life Insurance, a leading subsidiary, provided a total of 520billion won (about \$432 million) in 2011 and 2013 through the purchase of real estate including Hanwha Chemical headquarters building, buildings, and attached land .... Analyst at one brokerage said that several affiliated companies with cash have funded other affiliates so far, and explained that Hanwha Chemical could not exclude Hanwha's expansion of its defense business in terms of funding.
} 
Trade Commission over the period from 2005 to 2012. The results of the analysis are as follows. First, we find that the magnitude of internal funding, as measured by total payables to the related parties, is positively $(+)$ associated with investment inefficiency. Second, the interaction variables of total payables to the related parties and the wedge have a significant positive $(+)$ effect on investment inefficiency. In other words, the deterioration of investment efficiency due to the increase in total payables to the related parties was mainly caused by firms with a big wedge.

This result suggests that the effect of internal capital markets on investment efficiency of large business groups may be differentiated by the wedge that is proxy of the controlling shareholder's incentives. In other words, the controlling shareholders of a companies with a big wedge has stronger control over the company but less liability, which makes it easier for them to pursue their own interests (Bebchuk, Reinier \& Triantis, 2000; Kim \& Yi, 2006; Lee, 2013). It is interpreted that this financial support reduce the investment efficiency by being used for constructive investment of empire irrelevant to firm value or private use of controlling shareholder. Meanwhile, if the controlling shareholder has the cash flow right corresponding to the voting right because the wedge is low, the level of consensus with the external minority shareholder becomes greater. Therefore, unlike the group with a big wedge, it seems that funding through the internal capital market does not lead to inefficient investment.

This study provides additional evidence to previous studies concerning the investment efficiency of large business groups by taking into account the internal capital market, which is an important factor influencing the investment of large business groups and by considering the incentives for funding using the internal capital market. In addition, the results of this study are expected to provide implications for the regulatory policy of large business groups, which have recently become a prominent issue in Korea.

The rest of this paper is organized as follows. Section II reviews the literature and presents the hypotheses used in this paper. In Section III, we describe our methodology. We present descriptive statistics and the results of the empirical test in Section IV. Section V concludes with implications and study limitations.

\section{LITERATURE REVIEW AND HYPOTHESIS DEVELOPMENT}

\subsection{Literature Review}

\subsubsection{Internal Capital Market of Large Business Groups}

One of the most important characteristics of large business groups is the existence of an internal capital market. Park and Jung (2011) examined the internal capital market as well as efficient transactions through vertical integration as a special function that large groups of companies feature compared to independent firms. If external financing is difficult to obtain or the financing cost is high, it is possible to raise capital from affiliates belonging to business groups (Shin $\&$ Park, 1999). Even if funding among affiliates is made on competitive terms, such as in the external market, external financing may fail to raise funds irrespective of the conditions due to information asymmetry. In this regard, securing capital from affiliates can be advantageous for business groups (Park \& Jung, 2011). In addition, if long-term profitable businesses are in temporary financial distress, management activities can be continued by financing through the internal capital market. Therefore, it is possible to distribute the risk not only between companies but also over time through the internal capital market. As a result, investors' investment risk is reduced, thereby enhancing firm value and stock price of affiliates (Bae et al. 2006).

The existence of the internal capital market has negative aspects that facilitate the tunneling and support of insolvent affiliates (Johnson, Laporta, Lopez-de-Silanes \& Shleifer, 2000). In other words, the controlling shareholders of large business groups can maximize control over affiliates through the pyramid structure and the cross-shareholding, and allocate funds in favor of themselves through the internal capital market (Almeida \& Wolfenzon, 2006).

Previous studies have suggested two theoretical perspectives on the inducement of internal fund transactions by large business groups (Yoon, 2004). From the viewpoint of information asymmetry, Alchian (1969) has argued that the efficiency of allocating funds to the entire corporate group can be improved by avoiding information asymmetry of the external financial market through internal fund transactions. If the transaction cost in the external capital market due to information asymmetry is high, the internal capital market can be used to reduce costs. Khanna and Palepu 
(2000) have also argued that the internal capital market provides an opportunity for low-cost financing to affiliates in emerging countries where funding costs are high due to insufficient external capital markets. Thus, if the controlling shareholders of large business groups have more information than outside investors, it can allocate funds to affiliates with good investment opportunities for the efficient allocation of funds throughout the group (Stein, 1997). In addition, when firms use internal capital markets, it is less likely that important information about the firm will be divulged to the external capital market (Yoon, 2004). In the presence of such information asymmetry, the internal capital market can be used to increase the efficiency of the group as a whole and to increase the earning of each affiliate.

On the other hand, from the viewpoint of agent theory, the internal capital market may contain serious structural inefficiency. Scharfstein and Stein (2000) have argued that internal capital markets can lead to 'socialistic subsidies' in which business units with low investment opportunities and low productivity receive funding from business units with good investment opportunities. Rajan et al. (2000) also found that diversified firms tend to transfer resources from large business units with high profitability to business units with low investment opportunities. Claessens et al. (2002) identified that internal capital markets in emerging markets with a big wedge distress resulting from their complex ownership structure, such as pyramid structures and cross-shareholding, can exacerbate the agency problem between controlling shareholders and minority shareholders. In other words, there is the possibility that the controlling shareholder can transfer resources of the business group to affiliates that maximize their own private utility by using voting rights that exceed their ownership. This implies that the internal fund transactions of a large business group can profit the controlling shareholders at the expense of the minority shareholders (Yoon, 2004).

As previously mentioned, the internal capital markets, which is one of the most important characteristics of a large business group, are expected to vary in efficiency depending on ex ante incentives of controlling shareholders. In other words, if the motivation of the internal fund transaction is to mitigate imperfections of the market such as information asymmetry, it will enhance the efficiency of the entire business group. On the other hand, if the internal capital market is guided by incentives related to agency costs, such as securing control of controlling shareholders or detaching minority shareholders, it will result in undermining the efficiency of the business group.

\subsubsection{Investment Efficiency of Large Business Groups}

Previous studies on the internal capital market of large business groups have focused on one of the two incentives of the controlling shareholders discussed above and have studied whether the internal capital market is efficient. Some of these prior studies have discussed the efficiency of internal capital markets in relation to investment efficiency.

Jensen (1986) and Stulz (1990) pointed out the inefficiency of internal capital markets, and argued that the diversification firms reduces their firm value by showing the excess investment behavior using the funds to be paid to the shareholders. Scharfstein and Stein (2000) which conducted research on US composite companies found that diversified firms have lower investment levels than independent firms in industries with high investment opportunities, while diversified firms have higher investment levels than independent firms in industries with low investment opportunities. They interpreted these findings as suggesting that internal capital markets may hinder investment efficiency.

Stein (1997) has argued that funds are transferred from business units with significant funds available but with fewer investment opportunities compared with business units with greater investment opportunities. Yoon (2004) analyzed the direction of support in the internal capital markets of Korea's 5 largest chaebols and found that firms with large investment opportunities, as measured using Tobin's Q received funding from small firms with low investment opportunities. In addition, Claessens et al. (2002) found that newly-emerging affiliates experiencing rapid growth received funding from slower-growth affiliates. Based on these results, they argue that large business groups allocate internal funds according to growth potential for efficient allocation.

Analytical results concerning the investment efficiency of large business groups in Korea also contain mixed results. Kim (2011) suggests that firms in the business group invested more during the Korean foreign exchange crisis in 1998 but had lower profitability, and that investment efficiency was low due to a large amount of investment did not lead to higher profitability. Lee (2013) analyzed the factors affecting the allocation of internal funds to manufacturing companies belonging to the Korean chaebols. Results showed that there is a significant negative relationship between 
relative investment opportunities and internal fund allocation for chaebols. And as a result of this ineffective allocation of internal funds, the stock price return and the asset return rate of affiliated firms were found to be negatively affected. Cho and Kim (2013) also reported that companies belonging to a large business group were more likely to feature over-investment from related parties than those that do not belong to a large business group.

In contrast, Kim (2012) has argued that affiliates of a large business group have high investment efficiency due to affiliates of a large business group conduct more active investment and enhanced profitability from results of the empirical analysis using data following the Korean foreign exchange crisis. Lee et al. (2010) also found that following the Korean foreign exchange crisis, the over-investment tendency of large business group affiliates decreased. Kim (2010) suggests that the internal capital market exists in the chaebol even following the Korean foreign exchange crisis, and that many investments are made. Also, these investments used internal funds rather than external financing, and had a higher relation with firm value than comparative companies' investments. Yim et al. (2014) showed that firms of large business groups do not over-invest in comparison with other firms in the situation of high incentive to invest excessively, but invest excessively in conditions in which under-investment incentives are high.

As noted, studies on investment efficiency of large business groups feature mixed results. In addition, most related studies do not directly consider the role of internal capital markets, which is an important characteristic affecting the investment of large business groups. Even if the existence of the internal capital market was taken into consideration, it seems that the prior motivation in which the controlling shareholder uses the internal capital market was not distinguished. It is also important to understand not only post-performance but also ex ante incentive in judging the efficiency of internal fund transactions (Yoon 2004). Therefore, it is necessary to take into consideration the internal capital market and to consider ex ante incentive of the controlling shareholders in using the internal capital market in evaluating the investment efficiency of the large business group.

This study examines the effects of the internal capital market on investment efficiency of large business groups through total payables to related parties. In addition, we analyze the effect of ex ante motivation of controlling shareholder, which is represented by the divergence between the cash flow rights and voting rights of controlling shareholders(hereafter, wedge), on the relationship between the internal capital market and the investment efficiency of large business groups.

\subsubsection{Literature Review on the Wedge}

Wedge is a useful tool to clearly determine the intention of allocating internal funds within the Korean chaebol (Lee 2013). If the controlling shareholder has voting rights that exceed ownership, the benefit of the decision will correspond to the voting right, but the risk associated with it will be borne only by ownership (Fan \& Wong 2002). As a result, controlling shareholders have incentives to make decisions that maximize their private benefits in firms with a big wedge. In other words, depending on the wedge, the interests of the controlling shareholder and the decisionmaking behavior may differ.

Prior researches have suggested that the bigger wedge, the more opportunistic behavior of controlling shareholders results. LaPorta, Lopez-de-Silannes \& Shleifer (1999) found that in the case of East Asian countries, including Korea, the controlling shareholders exercise control over ownership through cross-shareholding and the pyramid ownership structure. Fan \& Wong (2002) reported that the controlling shareholder of firms with a big wedge is likely to extract the wealth of external minority shareholders, and accordingly, the bigger wedge, the more the information effect of earnings decreases.

Kim (2008) has presented results that decision-making at the business group level and the wedge of the whole business group directly affects decisions of individual affiliated companies. Lee, Chun \& Kim (2012) confirmed that as the wedge increases, the real activities earnings management increases even after controlling ownership. On this basis, they argue that the pursuit of opportunistic self-interests by controlling shareholders is enhanced by the separation of cash flow rights and voting rights. Seo, Lee \& Park (2013) suggested that the bigger wedge, the greater the management forecast bias. 
These studies show that the wedge is affecting various aspects of accounting transparency. This means that the wedge may significantly reflect the private motivation of the controlling shareholder. Therefore, as Lee (2013) has identified, the wedge is considered to be a useful tool to properly distinguish the motivation of controlling shareholders related to the use of internal capital markets.

\subsection{Hypothesis Development}

As previously discussed prior studies on the investment efficiency of large business group companies have presented mixed results. In addition, previous studies have frequently used a methodology that simply compares the average investment level or management performance of large business groups and control groups, and does not control other factors that may affect investment levels or performance (Kim, 2011; Kim, 2012; Lee et al. 2010). In addition a number of studies have suggested the existence of an internal fund market as one of the most important characteristics of a large business group, and explain the role of the internal fund market in relation to investment (Shin \& Park, 1999; Scharfstein \& Stein, 2000; Stein, 1997; Park \& Jung, 2011; Yoon, 2004). However, few studies have directly considered the impacts of the internal funding market on investment decisions.

Therefore, this study first examines the effect of funding levels of internal capital market on investment efficiency, which means an appropriate amount of funding is realize.

Previous studies have suggested that internal capital markets of large business groups may have a positive impact on investment efficiency. Shin and Park (1999) argued that Korean chaebols are less sensitive to investment-cash flow sensitivity than non-chaebols, and that these results are due to the internal capital market of Korean chaebols. Kim (2014) found that reduced investment resulting from conservatism is eased by the internal fund market that exists within large business groups. Kim (2010) reported that large business groups have more investment than non-chaebols due to the presence of internal capital markets. In this large business group, the internal capital market can increase the financial flexibility of the company and reduce financial constraints. In addition, there is the possibility to allocate internal funds effectively for investment and increase the value of the whole business group (Khanna \& Palepu, 2000; Stein 1997).

However, there are studies that suggest that the internal capital market can function inefficiently and negatively affect firm value. This problem can be caused mainly by the agent problem between the controlling shareholder and the external minority shareholder. In other words, from the viewpoint of agent theory, the internal capital market may have structural inefficiency. The controlling shareholders of chaebol firms can exercise their voting rights with greater effect higher than their ownership through pyramid structure and cross-shareholding, and have the possibility of overinvesting for constructing an empire by opportunistically using internal funds existing in a large business group. In this process, there is a possibility of 'socialist subsidies' to transfer internal funds from a business unit with excellent investment opportunities to a business unit with poor investment opportunities (Rajan et al. 2000; Scharfsten \& Stein, 2000; Lee, 2013). There is also the possibility of tunneling to relocate wealth to a company with a high controlling shareholder (Bae et al. 2006). As such, controlling shareholders are likely to take advantage of the internal capital market and try to take over wealth of minority shareholders or try to invest constructively in the empire. Therefore, funding through internal capital markets is expected to have a negative impact on investment efficiency.

So we try to analyze the effects of internal capital markets on investment efficiency by restricting the research subjects to large business groups and measuring the size of the funding through the internal capital market as the total payables to the related parties. For this, the hypothesis is set as follows.

Hypothesis 1: Ceteris paribus, as the total payables to the related parties increase, investment efficiency decreases.

Hypothesis 1 examines the effects of the internal capital market on the investment efficiency of a large business group. However, the effects of the internal capital market on investment efficiency may differ depending on the incentives of the controlling shareholder (Yoon, 2004). In other words, if the internal fund transaction is initiated due to incentives to compensate for market imperfections such as information asymmetry, it can contribute to enhancing the efficiency of the whole business group (Alchian, 1969; Khanna \& Palepu, 2000; Stein, 1997). Therefore, it will have a positive effect on the investment efficiency of companies belonging to a large business group. On the other hand, if the 
controlling shareholder utilizes the internal capital market in the incentive related to the agent cost to offset the minority shareholder's wealth such as securing the dominance or private use, it will act as a factor to undermine the efficiency of business group. (Claessens et al. 2002; Rajan et al. 2000; Scharfstein \& Stein, 2000). In this case, the use of the internal capital market is expected to have an adverse effect on the investment efficiency of companies belonging to a large business group.

Therefore, it is necessary to evaluate the investment efficiency of a large business group considering both the internal capital market which may have a significant influence on the investment decisions of the large business group and ex ante incentives of the controlling shareholder for utilization of the internal capital market. This study examines the effect of the incentive for internal capital markets on the relationship between internal capital markets and investment efficiency. To this end, we analyze whether the relation between the total payables to the related parties and the investment efficiency is differentiated according to the wedge.

The wedge is a useful tool for determining the intention of allocating internal funds within Korean chaebols (Lee 2013). The controlling shareholders of a large business group can secure voting rights of a greater proportion than the dividend level by using the pyramid structure or the cross-shareholding. The greater the gap between ownership and voting rights, results in shareholders pursuing private earnings using the internal capital market.

As the wedge is increase, the controlling shareholder can build a trench from the threat of external management control (Bebchuk, Reinier \& Triantis, 2000), the quality of financial reporting is lower and information asymmetry becomes larger (Kim \& Yi, 2006). Furthermore, in the case of a company with a big wedge, the controlling shareholder is likely to try to invest constructively in the empire irrespective of firm value because the controlling power is strong but the liability is small. Therefore, there is the possibility of transferring funds from the internal capital market to companies with a big wedge and utilizing for private use or low-profit investments.

On the other hand, in the case of a low degree of wedge, the controlling shareholder has ownership corresponding to the voting right, and thus the degree of agreement with the minority shareholder becomes higher. These companies can expect to provide investment funds using the internal capital market if there is a lack of investment funds available. In addition, if the wedge is low and the agent problem with minority shareholders is low, the controlling shareholder will only invest if the investor is confident about the investment. In other words, there is the possibility that it will not carry out over-investment that may adversely affect long-term firm value. Therefore, it is expected that funding through the internal capital market will improve investment efficiency. In order to verify the above discussion, hypothesis 2 is set as follows.

Hypothesis 2: Ceteris paribus, in the case of companies with a big wedge, the higher total payables to the related parties, the lower the investment efficiency.

\section{RESEARCH DESIGN}

\subsection{Methodology and Variable Definitions}

\subsubsection{Measurement of Investment Efficiency}

Tobin (1969) has argued that investment opportunities can be measured as a marginal Q, and McNichols and Stubben (2008) proposed the following appropriate investment equation based on Tobin(1969)'s argument.

$$
\begin{aligned}
& \text { INV }_{i, t}=\alpha_{0}+\beta_{1} Q_{i, t-1}+\beta_{2} Q_{i, t-1} * \text { Quartile }_{i, t-1}+\beta_{3} Q_{i, t-1} * \text { Quartile }_{i, t-1}+\beta_{4} Q_{i, t-1} \\
& \text { Quartile4 }_{i, t-1}+\beta_{b} \text { OCF }_{i, t}+\beta_{6} \text { Growth }_{i, t-1}+\beta_{7} \text { INV }_{i, t-1}+\varepsilon_{i, t}
\end{aligned}
$$

where

INV: cash flow from investing activities in year $t$ divided by tangible assets at the end of year $\mathrm{t}-1$

Q: $\quad$ Tobin's Q

Copyright by author(s); $\underline{\text { CC-BY }}$ 


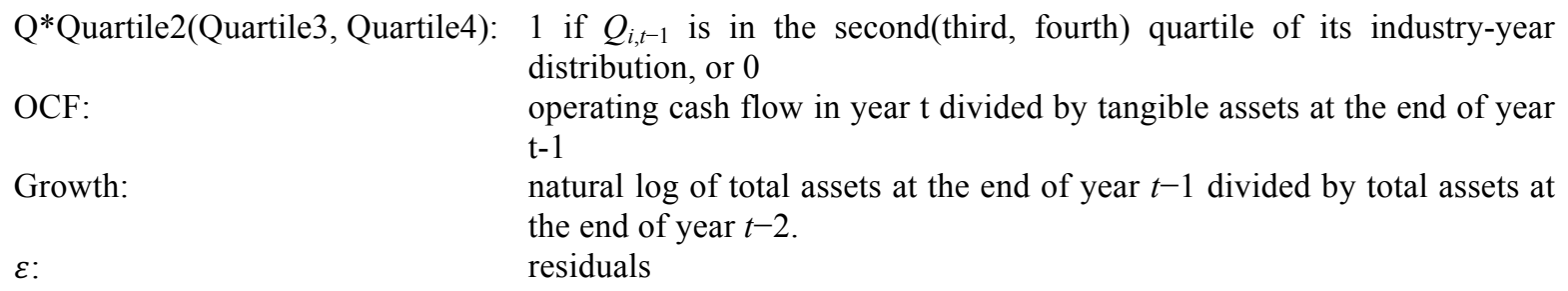

Growth: natural $\log$ of total assets at the end of year $t-1$ divided by total assets at the end of year $t-2$.

$\varepsilon$ : residuals

McNichols \& Stubben (2008) included asset growth at the beginning of the year and investment in the prior year in the equation to compensate for potential measurement errors in the traditional Tobin's Q. They also included an incremental coefficient for the quartiles of $Q$ to mitigate the assumption that the coefficient of Tobin's $Q$ is the same in each industry-year. The residual in Equation (1) implies an inefficient investment. This means that the larger the absolute value of the residual, the greater the investment inefficiency. In this study, we used the non-optimal investment level (absXINV), which is measured as the absolute value of the value obtained by subtracting the actual investment level from the optimal investment level estimated by Equation (1), as a proxy for the investment efficiency. Specifically, the above Equation (1) is estimated for each industry sample except the sample of large business groups by industry-year. The estimated coefficients were applied to the sample of large business groups to calculate the appropriate investment level for each company and year. Finally, after subtracting the actual investment level, the absolute value was applied to calculate the non-optimal investment level (absXINV).

\subsubsection{Regression Model}

To test $\mathrm{H} 1$ of this study, we used the following Equation (2).

$$
\begin{aligned}
& \text { absXINV }=\alpha_{0}+\beta_{1} T P R P_{t}+\beta_{2} S_{I Z E_{t}}+\beta_{3} L E V_{t}+\beta_{4} R O A_{t}+\beta_{5} F C F_{t-1}+I N D \text { Dummy }+ \\
& \text { YearDummy }+\varepsilon_{t}
\end{aligned}
$$

where

absXINV: $\quad$ abnormal investment level (absolute value of residual estimated through Equation (1))

TPRP: $\quad$ total payables (=borrowings and other payables) to related parties / total assets at year's beginning

SIZE: $\quad$ a natural logarithm of total assets

LEV: $\quad$ total liabilities / total assets

ROA: $\quad$ return on asset

FCF: $\quad$ free cash flow at year $\mathrm{t}-1 /$ total assets at the end of year $\mathrm{t}-2$

[(net income + depreciation expense - change in fixed assets - change in net working capital) / total assets at year' beginning]

IND Dummy: dummy variables for industry

Year Dummy: dummy variables for year

$\varepsilon: \quad$ residuals

The dependent variable in Eq. (2) is absXINV, which indicates the abnormal investment level, and the independent variable is TPRP, which represent the total payables to the related parties. ${ }^{2}$ If funding through related party transactions improves investment efficiency, we expect $\beta_{1}$ would have a negative (-) value, otherwise $\beta_{1}$ is expected to have a positive $(+)$ value. In addition, we included firm size (SIZE), debt ratio (LEV), return on asset (ROA), and free cash flow for the previous year (FCF) as control variables. These variables have been reported to affect the investment decisions of firms in previous studies.

\footnotetext{
${ }^{2}$ In this study, total payables to the related parties are used as a proxy for measuring the level of funding through internal capital markets. Current accounting standards (K-IFRS) require disclosure of information on transactions, receivables and payables when there is a transaction between related parties. Therefore, it is expected that it will be possible to determine the degree of funding through the internal capital market of a large business groups through information on receivables and payables among related parties. Specifically, total payables to related parties were measured by dividing the sum of borrowings and other payables to the related parties by the total assets.
} 
In order to test Hypothesis 2 that the effect of funding through internal capital markets on investment efficiency will be different depending on incentives of controlling shareholders, we include TPRP and the interaction variable of TPRP and WEDGEdum to the following Equation (3).

$$
\begin{aligned}
& \text { absXINV }=_{t}=\alpha_{0}+\beta_{1} T P R P_{t}+\beta_{2} W E D G E d u m_{t}+\beta_{3} T P R P * W_{E D G E d u m}+\beta_{4} \text { SIZE }_{t}+\beta_{5} L_{E V}+ \\
& \beta_{6} R_{t}+A_{t}+\beta_{7} F C F_{t-1}+I N D \text { Dummy }+ \text { YearDummy }+\varepsilon_{t}
\end{aligned}
$$

where

absXINV: $\quad$ abnormal investment level (absolute value of residual estimated through Equation (1))

TPRP: $\quad$ total payables (=borrowings and other payables) to the related parties / total assets at year beginning

WEDGEdum: 1 if wedge is greater than the median, 0 otherwise [WEDGE: (voting right - cash flow right) / (number of common stock - number of treasury stock)]

SIZE: $\quad$ a natural logarithm of total assets

LEV: $\quad$ total liabilities / total assets

ROA: $\quad$ return on assets

FCF: free cash flow at year $t-1 /$ total assets at the end of year $t-2$

[(net income + depreciation expense - change in fixed assets - change in net working capital) / total assets at year's beginning]

IND Dummy: dummy variables for industry

Year Dummy: dummy variables for year

$\varepsilon: \quad$ residuals

In order to measure the relative level of wedge, we set the dummy variable to 1 if the wedge of the individual firm is greater than the median of the sample, and 0 otherwise. Similar to many previous studies (Kim, Kim \& Kim, 2011), we define wedge as the difference between the voting right and the cash flow right of the controlling shareholder in a large business group. The voting rights are the shares that can be actually exercised by the controlling shareholder in a large business group, and they are measured by adding the percentage of the shares of the controlling shareholder and the relatives, executives, non-profit corporations, and affiliated companies. The cash flow rights are the percentage of equity shares owned by the controlling shareholder and relatives.

The main interest variable of Equation (3) is TPRP*WEDGEdum which is the interaction variable between the variable (TPRP) of total payables to the related parties and the dummy variable (WEDGEdum) of the wedge. If the coefficient $\left(\beta_{3}\right)$ of TPRP*WEDGEdum shows a significant positive value, Hypothesis 2 is supported.

\subsection{Sample Selection}

The purpose of this study is to analyze the effect of internal capital markets on investment efficiency of large business groups. Therefore, a sample was selected from companies belonging to a large business group designated by the Korea Fair Trade Commission. The sample period was 2005-2012, and the samples were selected according to the conditions presented in Table 1.

Table 1. Total sample selection

\begin{tabular}{l|c}
\hline \multicolumn{1}{c}{ Sample characteristics } & Number of firm-year observations \\
\hline Non-financial firms belonging to a large business group & 1,783 \\
\hline Less: Firms whose fiscal year does not end in December 31 & $(180)$ \\
\hline Firms that are not listed on the KOSPI market & $(308)$ \\
\hline Uunavailable data & $(106)$ \\
\hline Total & 1,189 \\
\hline
\end{tabular}


Banking and financial institutions were excluded from the sample due to the different accounting standard and financial statements compared with non-financial firms. Also, to control for the effects of different fiscal year-ends, we excluded firms whose fiscal year does not end on December 31. And we include only listed companies on the KOSPI to control for market differences.

Companies belong to large business group companies and wedge data were collected from Korea Fair Trade Commission's "Online Provision of Enterprises Information", and other financial data was extracted from the TS2000 database (Korea Listed Companies Association). In order to minimize the effects of outliers on the analytical results, we remove the top and bottom $1 \%$ of observations from the sample by performing a winsorization at the $1 \%$ level. The final sample consists of 1,189 firm-year observation.

\section{EMPIRICAL RESULTS}

\subsection{Descriptive Statistics and Correlation}

Table 2 displays descriptive statistics of the main variables used for hypotheses testing in this study. The mean (median) of the abnormal investment level (absXINV) is 0.1849 (0.1091). This means that the average level of abnormal investment of sample companies accounts for $18 \%$ of the tangible assets at year beginning. The mean (median) of TPRP is $0.0281(0.0124)$. As a result, the sample companies are comprised of $2.7 \%$ of total assets from the affiliates in the business group. The mean (median) of the divergence between the cash flow rights and voting rights of controlling shareholders (WEDGE) is 0.2679 (0.2693), and the average voting right exceeding cash flow right was about $27 \%$. Other control variables, such as SIZE, LEV, ROA, and FDF, are similar to previous studies.

Table 2. Summary of descriptive statistics

\begin{tabular}{l|c|c|c|c|c|c|c}
\hline \multicolumn{1}{|c|}{ Variables } & Mean & \multicolumn{1}{c|}{ Min } & Q1 & Median & \multicolumn{1}{c}{ Q3 } & Max & S.D. \\
\hline absXINV & 0.1849 & 0.0021 & 0.0494 & 0.1091 & 0.2064 & 1.8377 & 0.2658 \\
\hline TPRP & 0.0281 & 0.0000 & 0.0031 & 0.0124 & 0.0351 & 0.2456 & 0.0415 \\
\hline WEDGE & 0.2679 & 0.0000 & 0.0596 & 0.2693 & 0.4037 & 0.7901 & 0.2059 \\
\hline WEDGEdum & 0.4996 & 0.0000 & 0.0000 & 0.0000 & 1.0000 & 1.0000 & 0.5002 \\
\hline SIZE & 21.2512 & 17.8500 & 20.1536 & 21.2675 & 22.3773 & 24.6400 & 1.4914 \\
\hline LEV & 0.4871 & 0.0392 & 0.3344 & 0.5130 & 0.6312 & 0.9317 & 0.1999 \\
\hline ROA & 0.0442 & -0.2552 & 0.0110 & 0.0448 & 0.0856 & 0.2248 & 0.0759 \\
\hline FCF & 0.0183 & -0.4902 & -0.0365 & 0.0280 & 0.0908 & 0.4382 & 0.1376 \\
\hline
\end{tabular}

Number of observations: 1,189

The definitions of the variables are as follows: TPRP = total payables(=borrowings and other payables) to the related parties / total assets at year beginning; WEDGE = (voting right - cash flow right $) /($ number of common stock - number of treasury stock); WEDGEdum $=1$ if wedge is greater than the median, 0 otherwise; SIZE $=$ a natural logarithm of total assets; LEV $=$ total liabilities $/$ total assets; ROA= return on assets; FCF $=$ free cash flow at year $\mathrm{t}-1$ / total assets at the end of year $\mathrm{t}-2$ [(net income + depreciation expense - change in fixed assets - change in net working capital) / total assets at year's beginning]; IND Dummy = dummy variables for industry; Year Dummy = dummy variables for year; $\varepsilon$ : residuals.

Table 3 provides the Pearson's correlation between the variables used in the empirical analysis. In Table 3, the abnormal investment level (absXINV), which is a dependent variable of Equations 1 and 2, showed a positive $(+)$ correlation with the total payables to the related parties (TPRP). This suggests that investment efficiency decreases as the size of funding from related parties increases. On the other hand, the abnormal investment level (absXINV) does not have significant correlation with the cash flow rights and voting rights of controlling shareholders (WEDGE). However, since correlation analysis is a univariate analysis in which the influence of other variables is uncontrolled, multiple regression analysis is needed to clarify the relationship between variables.

As a result of the variance inflation factor (VIF) in order to confirm the possibility of multi-collinearity between the variables used in the analysis, the value of all variables was less than 4 . Therefore, it is judged that there is no distortion of the result due to the problem of multi-collinearity. 
Table 3. Pearson's correlations between key variables

\begin{tabular}{l|c|c|c|c|c|c|c|c}
\hline & absXINV & TPRP & WEDGE & WEDGEdum & SIZE & LEV & ROA & FCF \\
\hline absXINV & 1.0000 & $0.0750^{* * *}$ & -0.0192 & -0.0155 & $-0.1265^{* * *}$ & -0.0084 & 0.0146 & $0.0616^{* *}$ \\
\hline TPRP & & 1.0000 & $0.0988^{* * *}$ & $0.1157^{* * *}$ & $0.1471^{* * *}$ & $0.2094^{* * *}$ & -0.0207 & -0.0406 \\
\hline WEDGE & & & 1.0000 & $0.8386^{* * *}$ & $-0.2355^{* * *}$ & $0.0739^{* *}$ & $-0.1195^{* * *}$ & $-0.1406^{* * *}$ \\
\hline WEDGEdum & & & & 1.0000 & $-0.2336^{* * *}$ & $0.0794^{* * *}$ & $-0.1253^{* * *}$ & $-0.1241^{* * *}$ \\
\hline SIZE & & & & & 1.0000 & $0.1634^{* * *}$ & $0.1384^{* * *}$ & 0.0471 \\
\hline LEV & & & & & & 1.0000 & $-0.4172^{* * *}$ & $-0.3212^{* * *}$ \\
\hline ROA & & & & & & & 1.0000 & $0.3133^{* * *}$ \\
\hline FCF & & & & & & & & 1.0000 \\
\hline
\end{tabular}

$*, * *, * *$ significant at $10 \%, 5 \%$, and $1 \%$ levels, respectively.

Please refer to the note in Table 2 for the definitions of the variables.

\subsection{Regression Analysis}

Our regression results of Equation (2) for testing Hypothesis 1 are presented in Table 4. The regression coefficient of total payables to the related parties (TPRP) is 0.6636 , indicating a significant positive value at the $1 \%$ level. This is consistent with the hypothesis, and this implies that the larger the size of funding in the internal capital market, the worse the investment efficiency of the companies belonging to the large business group. This suggests that the internal fund transaction by large business groups may be conducted inefficiently in incentives to support poor subsidiaries or to transfer the wealth from external minority shareholders.

Table 4. Results of regression: The effect total payables to the related parties on investment efficiency

\begin{tabular}{|c|c|c|c|c|}
\hline$a b s X I N V_{t}=\alpha_{0}+\beta_{1} T$ & ${ }_{3} L E V_{t}+\beta_{4} R O A_{t}$ & Dummy $+Y e$ & & (2) \\
\hline Variables & Predicted Sign & Coefficient & t-value & \\
\hline Intercept & $+/-$ & 0.7529 & $6.59^{* * *}$ & \\
\hline TPRP & + & 0.6636 & $3.54^{* * *}$ & \\
\hline SIZE & - & -0.0260 & $-4.76^{* * *}$ & \\
\hline LEV & - & -0.0572 & -1.22 & \\
\hline ROA & - & 0.1407 & 1.21 & \\
\hline $\mathrm{FCF}$ & + & 0.0846 & 1.40 & \\
\hline IND Dummy & & \multicolumn{2}{|c|}{ Included } & \\
\hline Year Dummy & & \multicolumn{2}{|c|}{ included } & \\
\hline $\mathrm{F}$ value & & \multicolumn{2}{|c|}{6.29} & \\
\hline Adj. $\mathrm{R}^{2}$ & & \multicolumn{2}{|c|}{0.0856} & \\
\hline No. of Observations & & \multicolumn{2}{|c|}{1,189} & \\
\hline
\end{tabular}

$*, * *, * * *$ significant at $10 \%, 5 \%$, and $1 \%$ levels, respectively.

Please refer to the note in Table 2 for the definitions of the variables.

The results of Hypothesis 2 are shown in Table 5. Hypothesis 2 was verified through Equation (3), WEDGEdum and TPRP*WEDGEdum added to Equation (2), and the mean centering value ${ }^{3}$ of the interaction variables was used to control the multi-collinearity problem caused by the inclusion of interaction variables. Table 5 also shows the results of the under-investment sample $(\mathrm{XINV}<0)$ and the over-investment sample $(\mathrm{XINV}>0)$, as well as the results of the full sample. The deterioration of investment efficiency can be divided into under-investment and over-investment. We examined the effects of under-investment and over-investment internal capital.

The analysis results of the full sample show that the regression coefficient of TPRP is positive $(0.1129$, but not statistically significant, whereas the regression coefficient of TPRP*WEDGEdum is 0.8835 , which is significant at the 5\% level. In other words, for firms with a big wedge, the degree of increase in abnormal investment level was relatively large as the total payables to the related parties increased. Therefore, the deterioration in investment efficiency due to the increase in the total payables to the related parties can be interpreted as caused mainly by the

${ }^{3}$ TPRP*WEDGEdum is the value of the total payables to the related parties of an individual company, which is subtracted from the sample average, by interacting with the dummy variables of the wedge. 
group with a big wedge. As a result of supporting the hypothesis of this study, it suggests that the effect of the internal capital market of large business groups on investment efficiency may be differentiated by the incentives of controlling shareholder represented by the wedge. ${ }^{4}$

In other words, in the case of a company with a big wedge, the controlling shareholder has a strong control over the company, but the responsibility for the control is low so that the pursuit of the shareholder's private interest is easy (Bebchuk et al., 2000; Kim \& Yi, 2006; Lee, 2013). This can be interpreted as reducing investment efficiency by being used for constructive investment of the empire irrelevant to the firm value or private use of the controlling shareholder. On the other hand, if the wedge is low and the controlling shareholder has the cash flow rights corresponding to the voting rights, the degree of agreement with the external minority shareholders becomes higher. For this reason, unlike the group with a big wedge, it seems that funding through the internal capital market does not lead to the deterioration of investment efficiency.

On the other hand, the analysis of the under-investment sample and the over-investment sample shows that the regression coefficient of TPRP*WEDGEdum is not significant in the under-investment sample. However, in the case of the over- investment sample, the regression coefficient of TPRP*WEDGEdum shows a statistically significant positive value at the level of $5 \%$. Thus, funding for firms a big wedge seems to reduce investment efficiency by increasing over-investment rather than under-investment. In other words, companies with a big wedge can be interpreted as showing over-investment behavior by using the funds supported through the internal capital market due to incentive to build an empire, which leads to deteriorated investment efficiency.

Table 5. Results of regression: The effect of total payables to the related parties due to the wedge on investment efficiency $\operatorname{absXINV}_{t}=\alpha_{0}+\beta_{1} T P R P_{t}+\beta_{2}$ WEDGEdum $t+\beta_{3} T P R P * W E D G E d u m_{t}+\beta_{4}$ SIZE $_{t}+\beta_{5} L E V_{t}+\beta_{6} R_{0} A_{t}+\beta_{7} F C F_{t-1}$ + IND Dummy + YearDummy $+\varepsilon_{t}$

\begin{tabular}{|c|c|c|c|c|c|c|c|}
\hline \multirow{3}{*}{ Variables } & \multirow{3}{*}{$\begin{array}{c}\text { Predicted } \\
\text { Sign }\end{array}$} & \multirow{2}{*}{\multicolumn{2}{|c|}{ Full Sample }} & \multicolumn{4}{|c|}{ Reduced Sample } \\
\hline & & & & \multicolumn{2}{|c|}{$(\mathrm{XINV}<0)$} & \multicolumn{2}{|c|}{$(\mathrm{XINV}>0)$} \\
\hline & & Coefficient & t-value & Coefficient & t-value & Coefficient & t-value \\
\hline Intercept & $+/-$ & 0.8191 & $6.75^{* * *}$ & 0.6379 & $4.29^{* * *}$ & 1.1171 & $5.47^{* * *}$ \\
\hline TPRP & + & 0.1129 & 0.36 & -0.0472 & -0.13 & 0.2962 & 0.57 \\
\hline WEDGEdum & + & -0.0158 & -0.98 & -0.0298 & -1.52 & 0.0014 & 0.05 \\
\hline TPRP*WEDGEdum & + & 0.8835 & $2.33^{* *}$ & 0.5828 & 1.25 & 1.2390 & $1.97^{* *}$ \\
\hline SIZE & - & -0.0283 & $-4.95^{* * *}$ & -0.0180 & $-2.57^{* *}$ & -0.0452 & $-4.74^{* * *}$ \\
\hline LEV & - & -0.0537 & -1.14 & -0.0843 & -1.51 & -0.0181 & -0.22 \\
\hline ROA & - & 0.1461 & 1.25 & 0.3718 & $2.59^{* * *}$ & -0.1153 & -0.59 \\
\hline FCF & + & 0.0762 & 1.26 & -0.1551 & $-2.06^{* *}$ & 0.3528 & $3.53^{* * *}$ \\
\hline IND Dummy & & \multicolumn{2}{|c|}{ Included } & \multicolumn{2}{|c|}{ Included } & \multicolumn{2}{|c|}{ Included } \\
\hline Year Dummy & & \multicolumn{2}{|c|}{ Included } & \multicolumn{2}{|c|}{ Included } & \multicolumn{2}{|c|}{ Included } \\
\hline F value & & \multicolumn{2}{|c|}{$6.06^{* * *}$} & \multicolumn{2}{|c|}{$5.44^{* * *}$} & \multicolumn{2}{|c|}{$3.11^{* * *}$} \\
\hline Adj. $R^{2}$ & & \multicolumn{2}{|c|}{0.0893} & \multicolumn{2}{|c|}{0.1281} & \multicolumn{2}{|c|}{0.0898} \\
\hline No. of Observations & & \multicolumn{2}{|c|}{1,189} & \multicolumn{2}{|c|}{697} & \multicolumn{2}{|c|}{492} \\
\hline
\end{tabular}

*,**,*** significant at $10 \%, 5 \%$, and $1 \%$ levels, respectively.

Please refer to the note in Table 2 for the definitions of the variables.

\subsection{Additional Analysis}

\subsubsection{Analysis Using Traditional Tobin's Q Investment Function}

In the above analysis, we use the abnormal investment level estimated by using the model of McNichols \& Stubben (2008) as a proxy for investment efficiency. We re-test Hypothesis 1 and Hypothesis 2 using the abnormal investment

\footnotetext{
${ }^{4}$ As a result of mean and median difference analysis between the big and small wedge groups, it is found that the mean and median of the total payables to the related parties in the group with a big wedge are significantly higher than those of the groups with low wedge. Therefore, it seems that firms with a big wedge are not effectively investing such funds even though they receive a relatively large amount of internal funding as compared to the firms with low wedge. This suggests that controlling shareholders are increasing the level of funding for firms with a big wedge as means of private utility.
} 
level estimated as a traditional Tobin's Q investment function in order to increase the robustness of analysis results. The traditional Tobin's Q investment function is shown in Equation (4), and the abnormal investment level is measured consistent with McNichols \& Stubben (2008).

$$
I N V_{i, t}=\alpha_{0}+\beta_{1} Q_{i, t-1}+\beta_{2} O C F_{i, t}+\varepsilon_{i, t}
$$

INV: Cash flow from investing activities in year $\mathrm{t}$ divided by tangible assets at the end of year $\mathrm{t}-1$

Q: $\quad$ Tobin's Q

OCF: Operating cash flow in year $\mathrm{t}$ divided by tangible assets at the end of year $\mathrm{t}-1$

$\varepsilon: \quad$ Residuals

Table 6 shows the results using the traditional Tobin's Q investment function. First, the analysis of Hypothesis 1 shows that $\beta_{1}$ has a significant positive (+) value at the $10 \%$ level, which is not different from the analysis using McNichols \& Stubben (2008) model. Therefore, even if the level of abnormal investment measured by the traditional Tobin's Q investment function is used as a dependent variable, it can be confirmed that the analysis result does not change qualitatively. As a result of the re-test of Hypothesis 2 , the regression coefficient $\left(\beta_{3}\right)$ of RPTT*WEDGEdum still shows a significant positive $(+)$ value (at the $1 \%$ level). Thus, for firms with a big wedge, we can reaffirm that funding through internal capital markets further weakens investment efficiency.

Table 6. Results of regression: Using traditional Tobin's Q investment function as a proxy for investment efficiency absXINV $t_{t}=\alpha_{0}+\beta_{1}$ TPRP $P_{t}+\beta_{2}$ SIZE $_{t}+\beta_{3} L E V_{t}+\beta_{4} R O A_{t}+\beta_{5} F C F_{t-1}+I N D$ Dummy + YearDummy $+\varepsilon_{t}$

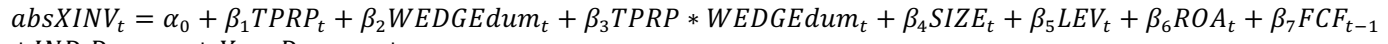
+ IND Dummy + YearDummy $+\varepsilon_{t}$

\begin{tabular}{|c|c|c|c|c|c|}
\hline \multirow{2}{*}{ Variables } & \multirow{2}{*}{$\begin{array}{l}\text { Predicted } \\
\text { Sign }\end{array}$} & \multicolumn{2}{|c|}{ Hypothesis 1} & \multicolumn{2}{|c|}{ Hypothesis 2} \\
\hline & & Coefficient & t-value & Coefficient & t-value \\
\hline Intercept & $+/-$ & 0.8079 & $7.82^{* * *}$ & 0.8614 & $7.88^{* * *}$ \\
\hline TPRP & + & 0.6632 & $3.92^{* * *}$ & -0.2016 & -0.72 \\
\hline WEDGEdum & + & & & -0.0053 & -0.36 \\
\hline TPRP*WEDGEdum & + & & & 1.3490 & $3.96^{* * *}$ \\
\hline SIZE & - & -0.0320 & $-6.49^{* * *}$ & -0.0336 & $-6.53^{* * *}$ \\
\hline LEV & - & 0.0168 & 0.39 & 0.0185 & 0.44 \\
\hline ROA & - & 0.1754 & $1.66^{*}$ & 0.1892 & $1.8^{*}$ \\
\hline FCF & + & 0.0852 & 1.56 & 0.0745 & 1.37 \\
\hline IND Dummy & & \multicolumn{2}{|c|}{ Included } & \multicolumn{2}{|c|}{ Included } \\
\hline Year Dummy & & \multicolumn{2}{|c|}{ Included } & \multicolumn{2}{|c|}{ Included } \\
\hline F value & & \multicolumn{2}{|c|}{$4.50^{* * *}$} & \multicolumn{2}{|c|}{$4.85^{* * *}$} \\
\hline Adj. $\mathrm{R}^{2}$ & & \multicolumn{2}{|c|}{0.0582} & \multicolumn{2}{|c|}{0.0694} \\
\hline No. of Observations & & \multicolumn{2}{|c|}{1,189} & \multicolumn{2}{|c|}{1,189} \\
\hline
\end{tabular}

$*, * *, * * *$ significant at $10 \%, 5 \%$, and $1 \%$ levels, respectively.

Please refer to Table 2 for the definitions of the variables except for the following. absXINV is the abnormal investment level and is the absolute value of residual estimated through Equation (4), which is a traditional Tobin's Q investment function.

\subsubsection{Analysis Using Net Payables to The Related Parties}

We used total payables to related parties as a proxy for the level of funding through the internal capital market. However, large business group companies may be able to provide funds to other affiliates while concurrently receiving funding from these affiliates. Table 7 shows the results of Hypothesis 2 using the net payables to the related parties as a proxy for the level of funding through the internal capital market. If the amount of payables to the related party is larger than the amount of the receivables, it means that the amount supported by the other companies in the group is relatively high, so that the funding from the internal capital market is high. Specifically, net payables to the related parties(NPRP) is measured by deducting loans and other receivables from borrowings and other payables to the related parties and dividing them by the total amount of receivables and payables to the related parties. Also, as in Table 5, NPRP*WEDGEdum is the mean centering value. 
As shown in Table 7, the model using the abnormal investment level as a dependent variable as estimated by McNichols \& Stubben (2008)'s investment model, found the regression coefficient of NPRP*WEDGEdum is 0.0427, showing that it is significantly positive at the $10 \%$ level. However, in the model using abnormal investment level estimated by the traditional Tobin's Q investment function as a dependent variable, the regression coefficient of NPRP*WEDGEdum showed positive value but was not significant. In the case of firms a big wedge, we partially confirmed that the level of abnormal investment increases as the net payables to the related parties increase. This implies that the effect of the internal capital market on investment efficiency can be differentiated by the incentives of the controlling shareholder represented by the wedge, as in the analysis using the total payables to related parties. Furthermore, firms with low wedge suggest that funding through the internal capital market may improve the investment efficiency by eliminating the lack of investment funds for profitable investment.

Table 7. Results of regression: Using net payables to the related parties as a proxy for level of funding through internal capital market

\begin{tabular}{|c|c|c|c|c|c|}
\hline \multirow{2}{*}{ Variables } & \multirow{2}{*}{$\begin{array}{l}\text { Predicted } \\
\text { Sign }\end{array}$} & \multicolumn{2}{|c|}{ McNichols \& Stubben's model } & \multicolumn{2}{|c|}{ Traditional Tobin's Q investment function } \\
\hline & & Coefficient & t-value & Coefficient & t-value \\
\hline Intercept & $+/-$ & 0.7472 & $6.05^{* * *}$ & 0.7417 & $6.64^{* * *}$ \\
\hline TPRP & + & -0.0307 & $-1.86^{*}$ & -0.0381 & $-2.55^{* *}$ \\
\hline WEDGEdum & + & -0.0107 & -0.66 & -0.0008 & -0.06 \\
\hline TPRP*WEDGEdum & + & 0.0427 & $1.78^{*}$ & 0.0214 & 0.99 \\
\hline SIZE & - & -0.0256 & $-4.41^{* * *}$ & -0.0291 & $-5.56^{* * *}$ \\
\hline LEV & - & -0.0220 & -0.47 & 0.0508 & 1.21 \\
\hline ROA & - & 0.1531 & 1.31 & 0.1879 & $1.78^{*}$ \\
\hline FCF & + & 0.0916 & 1.51 & 0.0969 & $1.77^{*}$ \\
\hline IND Dummy & & \multicolumn{2}{|c|}{ Included } & \multicolumn{2}{|c|}{ Included } \\
\hline Year Dummy & & \multicolumn{2}{|c|}{ Included } & \multicolumn{2}{|c|}{ Included } \\
\hline F value & & \multicolumn{2}{|c|}{$5.35^{* * *}$} & \multicolumn{2}{|c|}{$3.74^{* * *}$} \\
\hline Adj. $\mathrm{R}^{2}$ & & \multicolumn{2}{|c|}{0.0777} & \multicolumn{2}{|c|}{0.0504} \\
\hline No. of Observations & & \multicolumn{2}{|c|}{1,189} & \multicolumn{2}{|c|}{1,189} \\
\hline
\end{tabular}

$*, * *, * * *$ significant at $10 \%, 5 \%$, and $1 \%$ levels, respectively.

Please refer to the note in Table 2 for the definitions of the variables except for the following. NPRP is net payables to the related parties and is measured by deducting loans and other receivables from borrowings and other payables to the related parties and dividing them by the total amount of receivables and payables to the related parties $[=\{$ (borrowings and other payables to the related parties) $-($ loans and other receivables to the related parties) $\} /$ (borrowings and other payables to the related parties + loans and other receivables to the related parties)].

\section{CONCLUSION}

This study examines whether the effects of funding through internal capital markets on investment efficiency is differentiated by the incentives of controlling shareholders as measured by the wedge.

Large business groups in Korea have a profound impact on the domestic economy. These groups have been criticized for the concentration of economic power, collusive link between politics and business, and maximizing wealth of controlling shareholders, and have been subject to various regulations. On the other hand, large business groups are identified as having contributed to the development of the Korean economy through long-term and bold investment (Lee et al. 2010; Yim et al. 2014). Considering the influence of the large business group in the Korean economy and the conflicting perspectives concerning these groups, research related to large business groups has many implications.

One of the important characteristics of large business groups is the existence of the internal capital market (Park \& Jung 2011), Controlling shareholders are expected to use the internal capital market in the following two incentives: First, by using the internal capital market, information asymmetry existing in the external financial market can be avoided, thereby increasing the efficiency of allocating funds to the whole business groups (Alchian, 1969; Khanna \& Palepu, 2000; Stein, 1997). Second, there is the possibility that the controlling shareholder may transfer internal funds in order to maximize the controlling shareholder's private utility (Claessens et al. 2002; Scharfstein \& Stein 
2000; Yoon 2004). As a result, the efficiency of the internal capital markets of large business groups can be different due to these contradictory incentives of controlling shareholders.

Previous studies have examined the efficiency of internal capital markets in relation to investment efficiency, but results of are inconsistent (Kim, 2011; Kim, 2012; Lee et al. 2010; Kim, 2010; Lee, 2013; Yim et al. 2014; Cho \& Kim, 2013). In addition, most prior studies do not directly consider the role of internal capital markets, which may affect the investment of large business groups, nor does it distinguish between ex ante incentives of controlling shareholders using internal capital markets. This study examined the effects of the internal capital market of large business groups on investment efficiency through total payables to related parties and analyzed whether these effects are differentiated according to ex ante incentives of controlling shareholder represented by the wedge.

The main results of the analysis of 1,189 firm-year observations collected from Korean firms listed on the Korea Composite Stock Price Index (KOSPI) belonging to large business groups designated by the Korea Fair Trade Commission from 2005 to 2012 are as follows. First, we find that the magnitude of internal funding, as measured by total payables to the related parties, is positively $(+)$ associated with investment inefficiency. Second, the interaction variables of total payables to the related parties and the wedge have a significant positive $(+)$ effect on investment inefficiency. In other words, the deterioration of investment efficiency due to the increase in total payables to the related parties was mainly caused by firms with a big wedge. Third, for the robustness of the results, we analyzed additionally using the abnormal investment level estimated as a traditional Tobin's Q investment function and using the net payables to the related parties as a proxy for the size of the funding through the internal capital market. Equivalent results were obtained. As a result of additional analysis, the change of variables did not affect the results.

This study provides additional evidence for previous studies on investment efficiency of large business groups by considering both the internal capital market and incentives for funding using the internal capital market., which are important factors affecting the investment of large corporate groups. Also, the results of this study are expected to provide implications for the regulatory policy of large business groups which have recently become a prominent issue in Korea.

Meanwhile, this study measured the level of funding in the internal capital market through receivables and payables to the related parties such as borrowings and loans. There is the limitation in that the funding of companies belonging to large business groups can be achieved through the sale, purchase, and investment of assets. Also, there is the possibility that the empirical analysis model does not fully consider all variables, so there may be a problem concerning omitted variables.

\section{AUTHOR BIOGRAPHIES}

Minwoo Lee is a Ph. D. Candidate of School of Business at Yeungnam University, South Korea. Email: seabrain03@naver.com (the first author).

Yuwon Choi is a Part-time Lecturer of Accounting at Yeungnam University, South Korea. He holds a Ph.D. in Management (Accounting Concentration) from Yeungnam University, South Korea. Email: afoxyer@nate.com (the co-author).

Sanghyuk Moon is an Associate Professor of School of Business at Yeungnam University, South Korea. He holds a Ph.D. in Management (Accounting Concentration) from Sungkyunkwan University, South Korea. Email: shmoon@ynu.ac.kr (corresponding author).

\section{REFERENCES}

Alchian, A. A. (1969). Corporate management and property rights. Economic Policy and the Regulation of Corporate Securities, Washington, D.C.: American Enterprise Institute, 337-360.

Almeida, H., \& Wolfenzon, D. (2006). A Theory of Pyramidal Ownership and Family Business Groups. Journal of Finance 61(6), 2637-2680.

Bae, K.-H., Lim, C., \& Wei, K. (2006). Corporate Governance and Conditional Skewness in the World's Stock Market. Journal of Business 79, 2999-3028. 
Bebchuk, L., Reinier, K., \& Triantis, G. (2000). Stock Pyramids, Cross-Ownership, and Dual Class Equity: The Mechanism and Agency Costs of Separating Control from Cash-flow Rights. In: Morck, R. (Ed.), Concentrated Corporate Ownership. (University of Chicago Press, Chicago).

Cho, J. E., \& Kim, S. I., (2013). Related Party Transactions and Over-Investment. Korea International Accounting Review 48, 381-404. [Printed in Korean]

Claessens, S., Djankov, S., Fan, J. P., \& Lang, L. H. (2002). Disentangling the Incentive and Entrenchment Effects of Large Shareholdings. Journal of Finance 57(6), 2379-2408.

Fan, J., \& Wong, T. J. (2002). Corporate Ownership Structure and the Informativeness of Accounting Earnings in East Asia. Journal of Accounting and Economics 33(3), 401-425.

Jensen, M. C. (1986). Agency Costs of Free Cash Flow, Corporate Finance, and Takeovers. American Economic Review 76(2), 323-329.

Johnson, S., La Porta, R., Lopez-de-Silanes, F., \& Shleifer, A. (2000). Tunneling. American Economic Review 90, $22-27$.

Khanna, T., \& Palepu, K. (2000). Is Group Affiliation Profitable in Emerging Markets? An Analysis of Diversified Indian Business Groups. Journal of Finance 55(2), 867-891.

Kim, C. S. (2010). Internal Capital Markets and Chaebol Investments. Korean Journal of Financial Studies 39(4), 611-641. [Printed in Korean]

Kim, C. S. (2011). Effect of Group Affiliation on Investments: Evidence from the Global Economic Crisis. Asia-Pacific Journal of Financial Studies 40(6), 799-823.

Kim, C. S. (2012). Is Business Group Structure Inefficient? A Long-Term Perspective. Asia-Pacific Journal of Financial Studies 41(3), 258-285.

Kim, D. H., Kim, D. W., \& Kim, B. G. (2011). Ownership-Control Disparity and Dividend Policy in Korea: Perspectives of Agency Theory. Korean Journal of Financial Engineering 10(2), 99-124. [Printed in Korean]

Kim, J. B., \& Yi, C. H. (2006). Ownership Structure, Business Group Affiliation, Listing Status, and Earnings Management: Evidence from Korea. Contemporary Accounting Research 23(2), 427-264.

Kim, K. T. (2008). The Level of Wedge and Accounting Transparency. Accounting and Auditing Research 48, 73-108. [Printed in Korean]

Kim, Y. H. (2014). The Effects of Chaebol Firms on the Association between Accounting Conservatism and Firm's Investment Decisions. Korea International Accounting Review 56, 129-149. [Printed in Korean]

La Porta. R., Lopez-de-Silanes, F., \& Shleifer, A. (1999). Corporate Ownership around the World. Journal of Finance 54(2), 471-518.

Lee, A., Chun, S., \& Kim. S. (2012). Controlling Shareholders` Ownership Structure and Real Earnings Management. Korean Accounting Review 37(1), 157-189. [Printed in Korean]

Lee, K., Kim, J. Y., \& Lee. O. (2010). Long-Term Evolution of the Firm Value and Behavior of Business Groups: Korean Chaebols between Weak Premium, Strong Discount, and Strong Premium. Journal of the Japanese and International Economies 24(3), 412-440.

Lee, S. A. (2013). The Working of Internal Capital Market in Korean Chaebol. Journal of Knowledge Studies 11(2), $203-229$. [Printed in Korean]

McNichols, M., \& Stubben, S. (2008). Does Earnings Management affect Firms' Investment Decisions? The Accounting Review $83,1571-1603$.

Park, K. S., \& Jung. C. S. (2011). Tunneling or Propping: Functions of Business Groups under Spin-Offs. Korean Journal of Financial Studies 40(3), 461-499. [Printed in Korean]

Rajan, R. G., Servaes, H., \& Zingales, L. (2000). The cost of diversity: The diversification discount and inefficient investment. Journal of Finance 55(1), 35-80.

Scharfstein, D. S., \& Stein, J. C. (2000). The Dark Side of Internal Capital Markets: Divisional Rent-Seeking \& Inefficient Investment. Journal of Finance 55(6), 2537-2564.

Seo, Y. M., Lee, M. G., \& Park, W. J. (2013). The Effect of the Control-Ownership Disparity on Management Forecast Bias. Journal of Business Research 28(4), 49-76. [Printed in Korean]

Shin, H. H., \& Park, Y. S. (1999). Financing Constraints and Internal Capital Markets: Evidence from Korean Chaebols. Journal of Corporate Finance 5(2), 169-191.

Stein, J. C. (1997). Internal Capital Markets and the Competition for Corporate Resources. Journal of Finance 52(1), 111-133.

Stulz, R. M. (1990). Managerial Discretion and Optimal Financing Policies. Journal of Financial Economics 26(1), 3-27.

Tobin, J. (1969). A General Equilibrium Approach to Monetary Theory. Journal of Money, Credit and Banking 1(1), 15-29.

Yim, S. G., Lee, M. Y., \& Hwang, I. Y. (2014). The Investment Efficiency of Firms Belonging to Large Business Conglomerates. Korean Accounting Review 39(3), 91-134. [Printed in Korean]

Yoon, S. M. (2004). Motives and Direction of Fund Transactions in the Internal Capital Market of Chaebol. Korean Journal of Financial Studies 33(2), 45-82. [Printed in Korean] 